\title{
STAT3 is constitutively activated in chronic active Epstein-Barr virus infection and can be a therapeutic target
}

\author{
Erika Onozawa ${ }^{1,2}$, Haruna Shibayama ${ }^{1,2}$, Honami Takada ${ }^{1,2}$, Ken-Ichi Imadome ${ }^{3}$, \\ Sho Aoki ${ }^{2}$, Mayumi Yoshimori ${ }^{1,2}$, Norio Shimizu ${ }^{4}$, Shigeyoshi Fujiwara ${ }^{5,6}$, Takatoshi \\ Koyama ${ }^{2}$, Osamu Miura ${ }^{1}$ and Ayako Arai ${ }^{1,2}$ \\ ${ }^{1}$ Department of Hematology, Graduate School of Medical and Dental Sciences, Tokyo Medical and Dental University (TMDU), \\ Bunkyo-ku, Tokyo, Japan \\ ${ }^{2}$ Department of Laboratory Molecular Genetics of Hematology, Graduate School of Medical and Dental Sciences, Tokyo \\ Medical and Dental University (TMDU), Bunkyo-ku, Tokyo, Japan \\ ${ }^{3}$ Department of Advanced Medicine for Infections, National Center for Child Health and Development (NCCHD), Setagaya-ku, \\ Tokyo, Japan \\ ${ }^{4}$ Center of Stem cell and Regenerative Medicine, Institute of Research, Tokyo Medical and Dental University (TMDU), Bunkyo- \\ ku, Tokyo, Japan \\ ${ }^{5}$ Department of Allergy and Clinical Immunology, National Center for Child Health and Development (NCCHD), Setagaya-ku, \\ Tokyo, Japan \\ ${ }^{6}$ Division of Hematology and Rheumatology, Department of Medicine, Nihon University School of Medicine, Itabashi-ku, \\ Tokyo, Japan
}

Correspondence to: Ayako Arai, email: ara.hema@tmd.ac.jp

Keywords: chronic active Epstein-Barr virus infection; STAT3; T/NK-cell lymphoproliferative disorder; cytokines; ruxolitinib

Received: August 03, $2017 \quad$ Accepted: June 22, $2018 \quad$ Published: July 24, 2018

Copyright: Onozawa et al. This is an open-access article distributed under the terms of the Creative Commons Attribution License 3.0 (CC BY 3.0), which permits unrestricted use, distribution, and reproduction in any medium, provided the original author and source are credited.

\section{ABSTRACT}

Chronic active Epstein-Barr virus infection (CAEBV) is a lymphoproliferative disorder characterized by the clonal proliferation of EBV-infected T or NK cells and is related to severe systemic inflammation. This study aims to investigate STAT3 to elucidate the mechanism underlying the CAEBV development. We determined that STAT3 was constitutively activated in EBV-positive T- or NK-cell lines. We also determined that STAT3 was activated in the peripheral blood mononuclear cells (PBMCs) containing EBV-infected clonally proliferating $\mathrm{T}$ or NK cells in six of seven patients with CAEBV. We conducted direct sequencing of the STAT3 Src homology 2 (SH2) domain, which has previously been reported to be mutated in T- or NKcell neoplasms. No mutation was detected in the STAT3 SH2 domain in patients with CAEBV. Next, we investigated the effects of ruxolitinib, an inhibitor of both JAK1 and JAK2, which phosphorylates and activates STAT3. Ruxolitinib suppressed the phosphorylation of STAT3 in EBV-positive T- or NK-cell lines. Ruxolitinib also decreased the viable cell number of EBV-positive T- or NK-cell lines and PBMCs from patients with CAEBV. Furthermore, ruxolitinib suppressed the production of inflammatory cytokines in the cell lines and CAEBV patient-derived cells. In conclusion, constitutively activated STAT3, which promotes survival and cytokine production, could be a therapeutic target for CAEBV.

\section{INTRODUCTION}

Chronic active Epstein-Barr virus infection (CAEBV) was first reported as sustained infectious mononucleosis accompanied by fever, lymphadenopathy, and liver dysfunction in patients without known immunodeficiency [1]. Later, it was reported that EBV-infected, clonally proliferating $\mathrm{T}$ or NK cells had been detected in patients 
with the disorder [2-4]. Furthermore, aggressive T- or NKcell lymphoma can develop during the clinical course of CAEBV [5]. Hence, in the WHO classification, revised in 2017, CAEBV was classified into EBV-positive T- or NKcell lymphoproliferative disorder [6].

The two characteristics of CAEBV are a T- or NKcell lymphoproliferative disorder and an inflammatory disorder [7, 8]. Although EBV-infected T or NK cells in CAEBV clonally proliferate, they usually do not form solid tumors $[8,9]$. Instead, they can be detected in the peripheral blood and can infiltrate into organs, leading to their dysfunction. Furthermore, the transformation of these cells can lead to chemotherapy-resistant T- or NK-cell lymphoma or leukemia $[5,8,10]$. The other aspect of CAEBV is an inflammatory disorder. The main symptoms of CAEBV are equivalent to those of chronic inflammation, such as persistent fever, lymphadenopathy, liver dysfunction with hepatosplenomegaly, vasculitis, neuritis, and dermatitis [5]. This chronic inflammation eventually could develop into the life-threatening disorder hemophagocytic lymphohistiocytosis (HLH).

Unfortunately, the mechanism underlying the CAEBV development remains unclear. At present, no effective agent exists for CAEBV, and the only curative treatment strategy has been allogeneic hematopoietic stem cell transplantation (allo-HSCT) [9, 11]. However, only a limited number of patients are suitable candidates for allo-HSCT. Furthermore, the outcomes of allo-HSCT for patients with an active disease, accompanied by fever, liver dysfunction, vasculitis, and uveitis, were significantly poorer than the outcomes for patients with an inactive disease $[5,9]$. Hence, in order to establish effective medical treatments, it is imperative to determine the underlying mechanism of clonal proliferation of EBV-infected cells and sustenance of systemic inflammation in patients with CAEBV.

STAT3 is a transactivation factor that mediates proliferation and anti-apoptotic intracellular signaling. Constitutively activated STAT3 has been observed in numerous primary tumor cells as well as in tumor-derived cell lines obtained from patients, including those with lymphoid malignancies $[12,13]$. STAT3 is constitutively activated in EBV-positive neoplasms, post-transplant lymphoproliferative diseases (LPDs) [14], EBV-positive diffuse large B-cell lymphoma (DLBCL) [15], nasopharyngeal cancer (NPC) cells [16], and extranodal NK/T-cell lymphoma (ENKL) [17]. In addition, Küçük et al. reported the presence of activating mutations in the Src homology 2 (SH2) domain of STAT3 in EBV-positive $\gamma \delta \mathrm{T}$ - or NK-cell lines and in ENKL patient cells [18]. Interestingly, they also reported that a JAK1/2-specific inhibitor, AZD1480, inhibited the STAT3 activation as well as the proliferation of EBV-infected T- or NK-cell lines. As CAEBV is characterized by EBV-positive T- or NK-cells, we hypothesized that STAT3 was also constitutively activated in CAEBV. In addition, STAT3 induces inflammation by promoting the production of inflammatory cytokines, such as IFN- $\gamma$ and TNF-a, among others and by mediating the molecular signaling from their receptors [19]. This study aims to investigate STAT3 activation and its role in CAEBV using both cell lines and cells obtained from patients with CAEBV.

\section{RESULTS}

\section{STAT3 is constitutively activated in EBV-positive T- or NK-cell lines}

We investigated the STAT3 activation in EBVpositive T- or NK-cell (EBV-T/NK-cell) lines established from patients with EBV-positive T- or NK-cell lymphoid neoplasm. For the activation of STAT3, the phosphorylation of both tyrosine-705 and serine-727 is indispensable. At first, we conducted an immunoblotting assay to determine the phosphorylation of STAT3 (Figure 1A). Figures 1B and $1 \mathrm{C}$ show the relative intensity of the bands by the densitometry analysis. The serine-727 phosphorylation of STAT3 was detected in all cell lines under the maintenance condition (Figures 1A and 1C). However, the phosphorylation of tyrosine-705 was detected in EBVpositive T- or NK-cells, not in Jurkat, MOLT4, and HPBALL cells, which are EBV-negative T-cell lines (Figures $1 \mathrm{~A}$ and 1B). In KHYG1 cells, an EBV-negative NK-cell line, a little phosphorylation of tyrosine-705 of STAT3 was detected (Figures 1A and 1B). In addition, we investigated the localization of STAT3 in these cells, as activated STAT3 is phosphorylated and localized in the nucleus. Figure 1D shows that STAT3 was phosphorylated and detected in the cytoplasmic and nuclear fraction in EBV-T/NK-cell lines by western blotting. Figures $1 \mathrm{E}$ and $1 \mathrm{~F}$ show the densitometry analysis. EBV-negative cell lines did not exhibit tyrosine-phosphorylated STAT3 in the nucleus under these conditions (Figures 1D, 1E and 1F).

\section{STAT3 is constitutively activated in EBV-positive T- or NK-cells from patients with CAEBV}

We validated the results mentioned above in patientderived cells. In CAEBV, EBV-positive cells are detected in the peripheral blood. In this study, 14 patients with CAEBV (aged 18-64 years; five males, nine females; CD4 type: $n=4$; CD8 type: $n=4$; CD56 type: $n=3$; CD4 and CD56 double infection: $n=2$; and CD4 and CD8 double infection: $n=1$ ) were investigated. Table 1 presents the clinical findings, phenotype, and EBV DNA load of infected cells. The clonal proliferation of infected cells was detected in the peripheral blood mononuclear cells (PBMCs) of all patients. The EBV DNA load of the patient-derived PMBCs was $1.7 \times 10^{3}-2.6 \times 10^{5}$ (mean: 9.2 $\left.\times 10^{4}\right)$ copies $/ \mu \mathrm{g}$ DNA. We studied the STAT3 activation in the PBMCs obtained from five patients; the cells were isolated from the peripheral blood, immediately lysed, and used for western blotting (Figure 2A). Figures 2B and $2 \mathrm{C}$ show the relative intensity of the bands by the 
densitometry analysis. The lysate of SNT8 cells was a positive control. The phosphorylation of serine-727 was detected in the samples from patients as well as those from healthy donors. On the other hand, tyrosine-705 of STAT3 was significantly phosphorylated in four of five patient cells. The non-detection of the tyrosine phosphorylation in Case 9 could present the negative or weak activation of STAT3, or could be attributed to the low rate of EBVpositive cells in the PBMCs (Table 1), because STAT3 was constitutively expressed in PBMCs. Taken together, the phosphorylation of both tyrosine-705 and serine-727 was detected in patients' samples. In addition, we
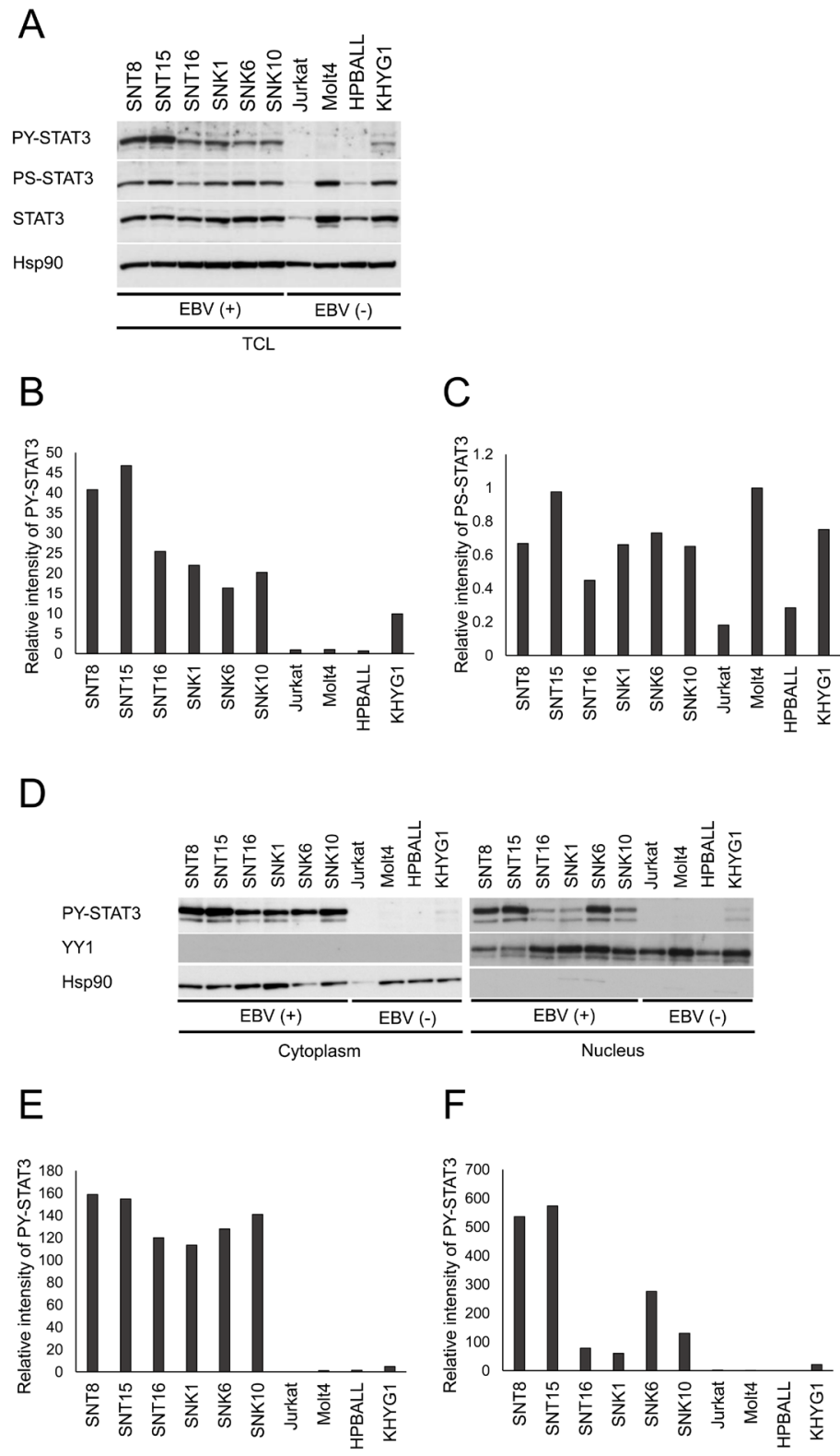

Figure 1: STAT3 is constitutively activated in EBV-positive T- or NK-cell lines. (A) Western blotting for the phosphorylation of cell lines. Total cell lysates (TCL) were prepared, resolved by SDS-PAGE, and immunoblotted with antibodies, as indicated. STAT3 is constitutively phosphorylated in EBV-positive T- or NK-cell (EBV-T/NK-cell) lines but not in EBV-negative T- or NK-cell lines. Tyrosinephosphorylated STAT3 (PY-STAT3) is detected in EBV-T/NK cell lines. Serine-phosphorylated STAT3 (PS-STAT3) is detected in all cell lines. EBV-negative cell lines do not exhibit or demonstrate a little phosphorylation of tyrosine. (B and $\mathbf{C}$ ) the relative intensities of PY-STAT3 (B) and PS-STAT3 (C) bands of (A) were determined as ratio to total STAT3 by densitometry. MOLT4 was determined as a control. (D) Western blotting for STAT3 localization in EBV-T/NK-cell lines. Tyrosine-PY-STAT3 is localized in the nucleus in EBV-T/ NK-cell lines but not in EBV-negative T- or NK-cell lines. Hsp90 and YY1 are proteins that were localized to the cytoplasm and nucleus, respectively. (E and $\mathbf{F}$ ) the relative intensities of PY-STAT3 bands (D) of cytoplasm (E) and nucleus (F). The intensites were determined as ratio to Hsp90 (E) and YY1 (F), respectively by densitometry. MOLT4 was determined as a control. 
Table 1: The characteristics of patients

\begin{tabular}{|c|c|c|c|c|c|c|c|c|}
\hline Case & Gender & Age & $\begin{array}{c}\text { EBV- } \\
\text { Infected } \\
\text { cells }\end{array}$ & Clinical findings & $\begin{array}{l}\text { Clonality of the } \\
\text { EBV-infected } \\
\text { cells }\end{array}$ & 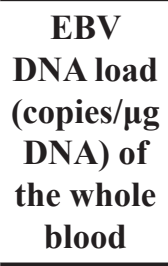 & $\begin{array}{c}\text { EBV DNA } \\
\text { load (copies/ } \\
\mu \mathrm{g} \text { DNA) of the } \\
\text { EBV-infected } \\
\text { cells fraction in } \\
\text { the PBMCs }\end{array}$ & $\begin{array}{l}\text { The rate of the } \\
\text { EBV-infected } \\
\text { cell fractions in } \\
\text { the PBMCs }\end{array}$ \\
\hline 1 & $\mathrm{~F}$ & 25 & $\mathrm{CD} 4$ & $\begin{array}{c}\text { Fever, liver } \\
\text { dysfunction, } \\
\text { lymphadenopathy }\end{array}$ & Monoclonal & $7.0 \times 10^{4}$ & $2.2 \times 10^{5}(\mathrm{CD} 4)$ & $71.2 \%$ \\
\hline 2 & M & 45 & $\mathrm{CD} 4$ & Fever, sMBA & Monoclonal & $1.7 \times 10^{3}$ & $1.7 \times 10^{4}(\mathrm{CD} 4)$ & NE \\
\hline 3 & $\mathrm{M}$ & 34 & CD4 & Fever & Monoclonal & $5.7 \times 10^{4}$ & $4.9 \times 10^{5}(\mathrm{CD} 4)$ & $54.3 \%$ \\
\hline 4 & M & 20 & $\mathrm{CD} 4$ & $\begin{array}{c}\text { Fever, liver } \\
\text { dysfunction, } \\
\text { lymphadenopathy }\end{array}$ & Monoclonal & $2.0 \times 10^{5}$ & $1.5 \times 10^{5}(\mathrm{CD} 4)$ & $60.5 \%$ \\
\hline 5 & $\mathrm{~F}$ & 38 & $\mathrm{CD} 8$ & $\begin{array}{c}\text { Fever, liver } \\
\text { dysfunction, } \\
\text { lymphadenopathy }\end{array}$ & Monoclonal & $1.4 \times 10^{5}$ & $3.9 \times 10^{5}(\mathrm{CD} 8)$ & $76.5 \%$ \\
\hline 6 & $\mathrm{~F}$ & 21 & CD8 & $\begin{array}{l}\text { Fever, liver } \\
\text { dysfunction }\end{array}$ & Monoclonal & $4.7 \times 10^{4}$ & $1.7 \times 10^{4}(\mathrm{CD} 8)$ & $50.0 \%$ \\
\hline 7 & $\mathrm{~F}$ & 64 & CD8 & $\begin{array}{c}\text { Fever, liver } \\
\text { dysfunction, } \\
\text { lymphadenopathy }\end{array}$ & Monoclonal & $2.6 \times 10^{5}$ & $1.2 \times 10^{6}(\mathrm{CD} 8)$ & $51.0 \%$ \\
\hline 8 & M & 28 & CD8 & $\begin{array}{c}\text { Fever, liver } \\
\text { dysfunction, } \\
\text { lymphadenopathy, } \\
\text { neuritis }\end{array}$ & Monoclonal & $1.9 \times 10^{3}$ & $4.1 \times 10^{5}(\mathrm{CD} 8)$ & $\mathrm{NE}$ \\
\hline 9 & $\mathrm{~F}$ & 18 & CD56 & sMBA & Monoclonal & $5.2 \times 10^{4}$ & $\begin{array}{c}1.6 \times 10^{6} \\
(\mathrm{CD} 56)\end{array}$ & $3.8 \%$ \\
\hline 10 & $\mathrm{~F}$ & 48 & CD56 & $\begin{array}{c}\text { Fever, sMBA, } \\
\text { HLH }\end{array}$ & Monoclonal & $8.6 \times 10^{4}$ & $\begin{array}{l}1.6 \times 10^{5} \\
(\mathrm{CD} 56)\end{array}$ & $10.0 \%$ \\
\hline 11 & $\mathrm{~F}$ & 23 & CD56 & sMBA & Monoclonal & $5.1 \times 10^{4}$ & $\begin{array}{c}4.6 \times 10^{5} \\
(\mathrm{CD} 56)\end{array}$ & $17.9 \%$ \\
\hline 12 & M & 37 & $\begin{array}{l}\text { CD4, } \\
\text { CD56 }\end{array}$ & $\begin{array}{c}\text { Fever, } \\
\text { lymphadenopathy }\end{array}$ & Monoclonal & $1.9 \times 10^{5}$ & $\begin{array}{c}1.9 \times 10^{5} \\
(\mathrm{CD} 4), 1.1 \times 10^{6} \\
(\mathrm{CD} 56)\end{array}$ & $\begin{array}{l}30.0 \%(\mathrm{CD} 4) \\
0.2 \%(\mathrm{CD} 56)\end{array}$ \\
\hline 13 & $\mathrm{~F}$ & 18 & $\begin{array}{l}\text { CD4, } \\
\text { CD56 }\end{array}$ & $\begin{array}{c}\text { Fever, } \\
\text { polyneuropathy, }\end{array}$ & Monoclonal & $6.0 \times 10^{4}$ & $\begin{array}{l}1.7 \times 10^{5}(\mathrm{CD} 4), \\
\left.7.1 \times 10^{6} \mathrm{CD} 56\right)\end{array}$ & $\begin{array}{l}35.2 \%(\mathrm{CD} 4) \\
2.3 \%(\mathrm{CD} 56)\end{array}$ \\
\hline 14 & $\mathrm{~F}$ & 22 & $\begin{array}{l}\text { CD4, } \\
\text { CD8 }\end{array}$ & Fever, HV & Monoclonal & $7.2 \times 10^{4}$ & $\begin{array}{l}1.8 \times 10^{4}(\mathrm{CD} 4) \\
1.4 \times 10^{5}(\mathrm{CD} 8)\end{array}$ & $\begin{array}{c}41.2 \%(\mathrm{CD} 4) \\
51.7 \%(\mathrm{CD} 8)\end{array}$ \\
\hline
\end{tabular}

F, female; M, male; NE, not examined

EBV; Epstein-Barr virus, PBMCs; peripheral blood mononuclear cells, F; female, M; male, sMBA; severe mosquito bite allergy, NE; not examined, HLH; Hemophagocytic lymphohistiocytosis, HV; hydroa vacciniforme-like eruption

investigated the expression of STAT3-inducible genes by the microarray analysis. The fractions containing EBVinfected cells were isolated from the PBMCs of patients, Cases 1, 7, and 11, whose EBV-positive cells were CD4-
, CD8-, and CD56-positive cells, respectively. For the isolation, we used antibody-conjugated magnetic beads against surface markers on infected cells. In addition, the RNA was extracted from cells and used for the microarray 
analysis. Figure 2D shows that the expression of STAT3inducible genes, including $I F N-\gamma$, was generally enhanced in the patient-derived T- or NK-cell fractions that included EBV-positive cells. Furthermore, we examined the activation and localization of STAT3 in EBV-positive Tor NK-cells from the patients. In Cases 3 and 11, EBVinfected cells were CD4- and CD56-positive, respectively (Table 1). We isolated CD4- or CD56-positive cells from the PBMCs of patients and healthy donors using antibody-conjugated magnetic beads. Figure 2E shows the flow cytometry for the isolated cells, confirming that a majority of the isolated cells were positive for CD4 or CD56. Figure 2F shows the localization of tyrosinephosphorylated STAT3 (PY-STAT3) in isolated CD4- or CD56-positive cells. PY-STAT3 was detected not only in the cytoplasm but also in the nucleus of patient-derived CD4- or CD56-positive cells, whereas it was not detected in CD4- or CD56-positive cells from healthy donors. EBV infection was determined by the LMP1 expression in patient-derived CD4- or CD56-positive cells. These results indicated that STAT3 was constitutively activated in PBMCs fractions containing EBV-infected T or NK cells in CAEBV. In Case 3 and 11, STAT3 was constitutively activated in EBV-infected T or NK cells. At present, however, it is not clear whether this activation is specific to EBV-infected cells, because we could not examine infected and un-infected cells separately.

\section{Mutation analysis of the STAT3 SH2 domain in EBV-positive T- or NK-cells}

The SH2 domain of STAT3 frequently exhibits gain-of-function mutations in large granular lymphocytic leukemia. Mutations in this domain have also been identified in $\gamma \delta \mathrm{T}$ cells from lymphoid neoplasms including ENKL $[18,20]$. Hence, we investigated the mutation status of the SH2 domain in EBV-positive T- or NK-cells from patients with CAEBV. Three of six EBVpositive T- or NK-cell lines: SNT8; SNT15; and SNK6, presented a mutation in the SH2 domain of STAT3 (D661Y in SNT8 and SNK6, and Y640F in SNT15; Table 2; Supplementary Figure 1). These mutations were identical to those previously reported [18]. However, no mutation was detected in the PBMCs analyzed, which included EBV-infected and clonally proliferating $\mathrm{T}$ or NK cells from 14 patients with CAEBV.

\section{The effects of JAK1/2 inhibitors on the phosphorylation of STAT3 in EBV-positive T- or NK-cell lines}

The results described above suggest that the constitutive activation of STAT3 might be induced by an upstream intracellular signaling molecule. JAKs are kinases that phosphorylate and activate STAT3. Hence, we investigated the effects of JAK inhibitors on the phosphorylation of STAT3 in EBV-positive T- or NK-cell lines. Interestingly, the tyrosine-705 phosphorylation of STAT3 was inhibited by ruxolitinib (a JAK1/2 inhibitor), tofacitinib (a JAK3 inhibitor), and JAK inhibitor 1 (a JAK $1 / 2 / 3$ inhibitor) in a dose-dependent manner even in cell lines harboring the mutation (Figure 3 ). The phosphorylation of serine-727 of STAT3 was not clearly suppressed after the treatment. Dimethyl sulfoxide (DMSO), a solvent for inhibitors, did not exhibit significant effects on the phosphorylation (Supplementary Figure 2). Thus, even in cells with the SH2 domain mutation, the constitutive activation of STAT3 could be inhibited in EBV-positive T- or NK-cell lines by the inhibition of JAKs.

\section{The biological effects of ruxolitinib on EBV- positive T- or NK-cell lines and CAEBV patient- derived cells}

From the three inhibitors, we selected ruxolitinib, the effective concentration of which was identical to that of its clinical use. We investigated the effects of ruxolitinib on the proliferation and survival of EBVpositive T- or NK-cells. The XTT assay demonstrated that ruxolitinib suppressed the viable cell number of EBV-positive T- or NK-cell lines in a dose-dependent manner (Figure 4A). In addition, ruxolitinib suppressed a viable cell number of CAEBV patient-derived PBMCs in a dose-dependent manner (Figure 4B). Ruxolitinib also suppressed the number of healthy donor-derived PBMCs. However, under the concentration of $0.25 \mu \mathrm{M}$, which can be actually achieved in patients, the number of patientderived PBMCs was decreased whereas that of healthy donor-derived PBMCs was not. As shown in Figure 4C, ruxolitinib induced cellular apoptosis in SNT16, although it was not remarkable in SNT8, SNT15, and SNK6 cells. Finally, we investigated the effects on cytokine production. Figures $5 \mathrm{~A}$ and $5 \mathrm{~B}$ show that ruxolitinib suppressed the mRNA production of inflammatory cytokines, IFN- $\gamma$ and TNF- $a$ in EBV-positive T- or NKcell lines. Furthermore, ruxolitinib suppressed the mRNA production of inflammatory cytokines IFN- $\gamma$ (Figure 5C) and TNF-a (Figure 5D) in the CAEBV patient-derived PBMCs. The mRNA of interleukin-6 (IL-6) was not detected in these cells (data not shown). The viability of each cells was approximately $80 \%$, and $60-80 \%$, in the cell lines and patients' cells, respectively (Supplementary Figure 3).

\section{DISCUSSION}

Our results indicated that STAT3 was constitutively activated in EBV-positive T- or NK-cells from patients with CAEBV. This study did not detect activating mutations of STAT3 in these cells. Furthermore, the tyrosine phosphorylation of STAT3, as well as the survival, 

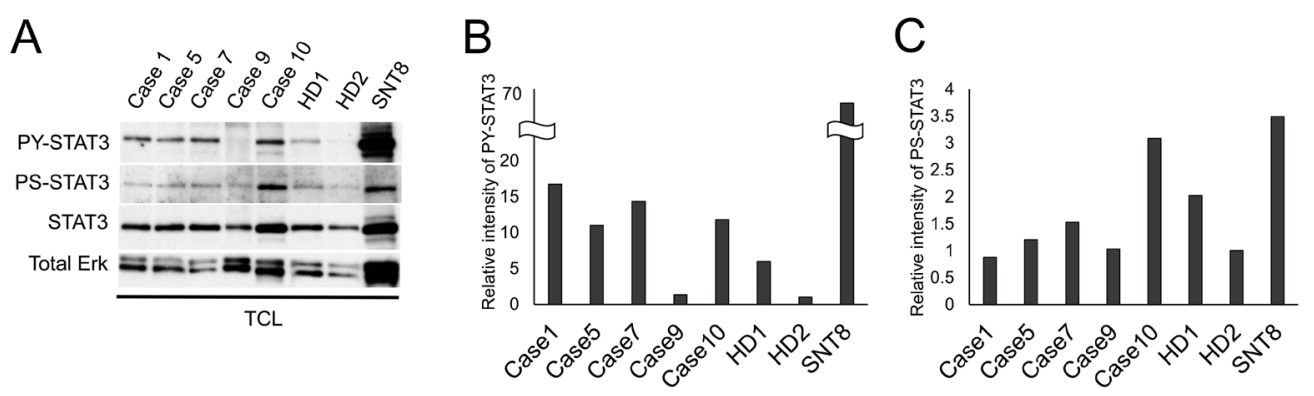

D

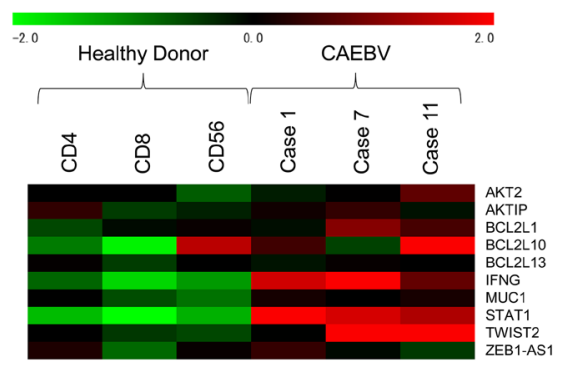

E
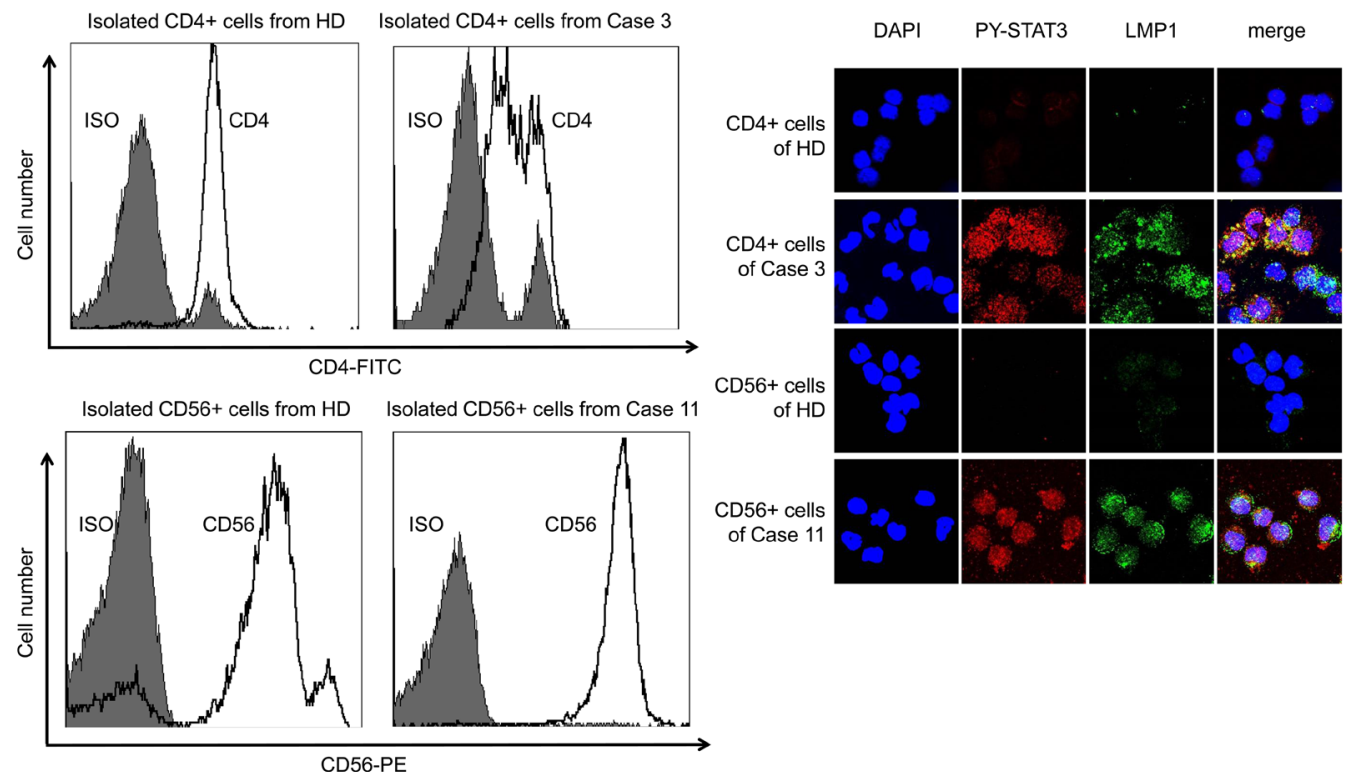

F 
Table 2: Sequence analysis of the SH2 domain of STAT3 of EBV-positive T- or NK-cell lines

\begin{tabular}{lccc}
\hline Cell lines & Exon 19 & Exon 20 & Exon 21 \\
\hline SNT8 & WT & WT & D661Y \\
SNT15 & WT & WT & Y640F \\
SNT16 & WT & WT & WT \\
SNK1 & WT & WT & WT \\
SNK6 & WT & WT & D661Y \\
SNK10 & WT & WT & WT \\
\hline
\end{tabular}

was suppressed by ruxolitinib even in cell lines harboring the activating mutation of STAT3. Although mutations detected in the SH2 domain upregulated the dimerization of STAT3 [18], our results indicated that the activation of STAT3 depended on the tyrosine phosphorylation.

The underlying mechanism for the phosphorylation of STAT3 in CAEBV could be attributed to several factors. First, the activation of JAK kinases which directly phosphorylates and activates STAT3, should be examined. Previously, gain-of-function mutations have been reported in JAK1 or JAK3 in some neoplasms, leukemia, breast cancer, lung cancer, hepatocellular carcinoma [21], and NK-lymphoma cells [22-24]. Interestingly, an association between the JAK1 expression and the STAT3 activation has been reported in T-cell lymphomas [25]. In addition, Src family kinases can activate STAT3. Reportedly, LMP1 activates Src kinases in EBV-infected B-cells [26], and this activity should be investigated in EBV-positive T- or NK-cells in CAEBV.

Several studies have suggested that STAT3 might be activated downstream of LMP1 through the activation of NF-кB. In EBV-infected B cells or epithelial cells, $\mathrm{NF}-\kappa \mathrm{B}$ is activated by $\mathrm{C}$-terminal-activating region 1 (CTAR1) of LMP1 [27, 28]. In addition, we recently determined that $\mathrm{NF}-\kappa \mathrm{B}$ was constitutively activated through LMP1, promoting survival in EBV-positive

\section{B}

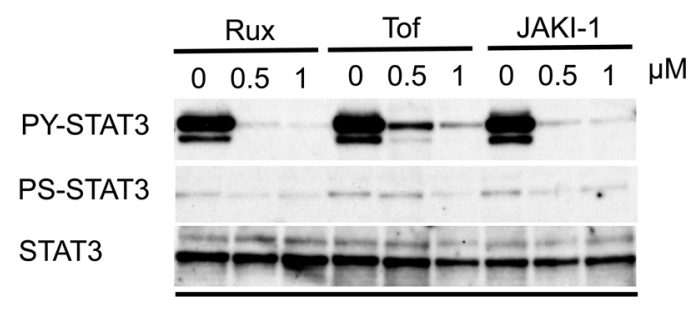

TCL (SNT15)

$D$

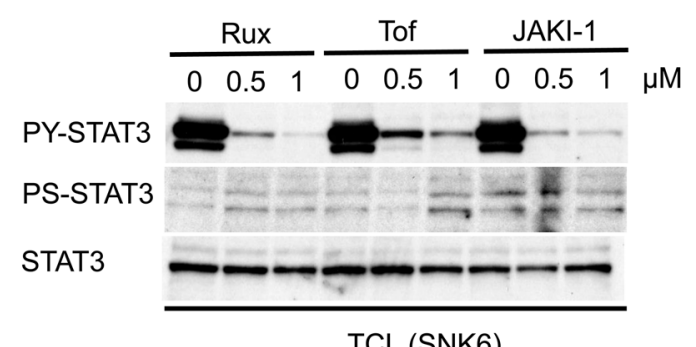

TCL (SNK6)

Figure 3: JAK inhibitors suppress the constitutive phosphorylation of STAT3 in EBV-positive T- or NK-cell lines. (AD) Western blotting for the phosphorylation of cell lines treated with JAK inhibitors. Total cell lysates (TCL) were prepared, resolved by SDS-PAGE, and immunoblotted with antibodies, as indicated. The phosphorylation of tyrosine-705-STAT3 in cell lines was suppressed by JAK inhibitors in a dose-dependent manner: SNT8 (A); SNT15 (B); SNT16 (C); and SNK6 (D). The phosphorylation of serine-727 was not clearly suppressed. Rux, ruxolitinib; Tof, tofacitinib; JAKI1, Jak inhibitor 1. 
T- or NK-cells obtained from patients with CAEBV [29]. Chen et al. reported that NF- $\kappa$ B activates STAT3 through IL-6 production in EBV-infected epithelial cells [30]. They mentioned that IL-6 associates with IL6R/ gp130 expressed on cells and activates STAT3 through the JAK activation in cells by autocrine mechanisms. In addition, IL-6 is elevated in the serum of patients with CAEBV [19]. Although the mRNA of IL-6 was not detected in EBV-positive T- or NK-cell lines in this study,
IL-6 can be produced by other inflammatory cells such as macrophages in CAEBV. Reportedly, activated NF$\kappa \mathrm{B}$ induces the expression of a receptor tyrosine kinase epidermal growth factor receptor (EGFR), leading to the STAT3 activation by the phosphorylation on Y-705 in NPC cells. According to the study by Nosbaum et al., EGFR can be inducibly expressed on T or NK cells [31]. Thus, EGFR could also mediate the STAT3 activation in EBV-positive T- or NK-cells. The expression and the activation of EGFR
A

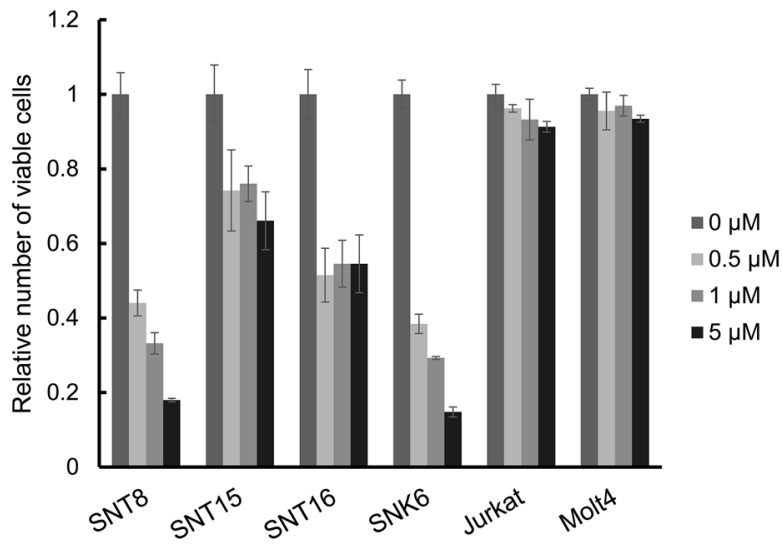

B

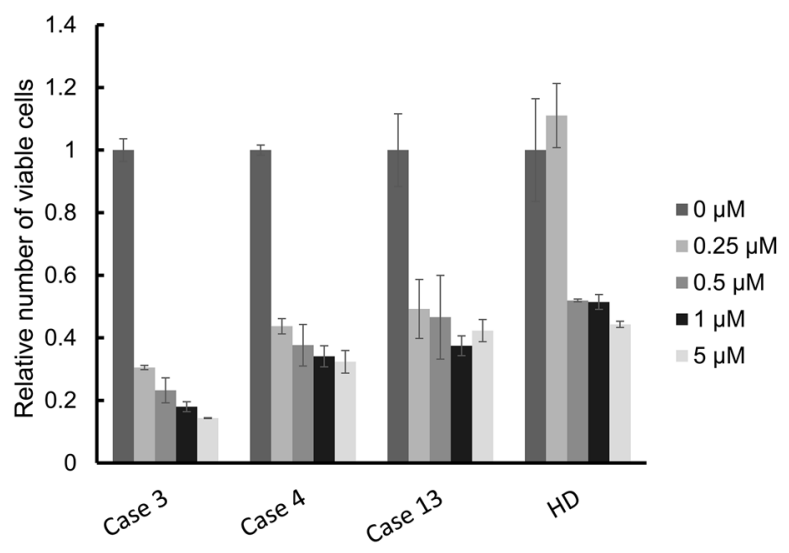

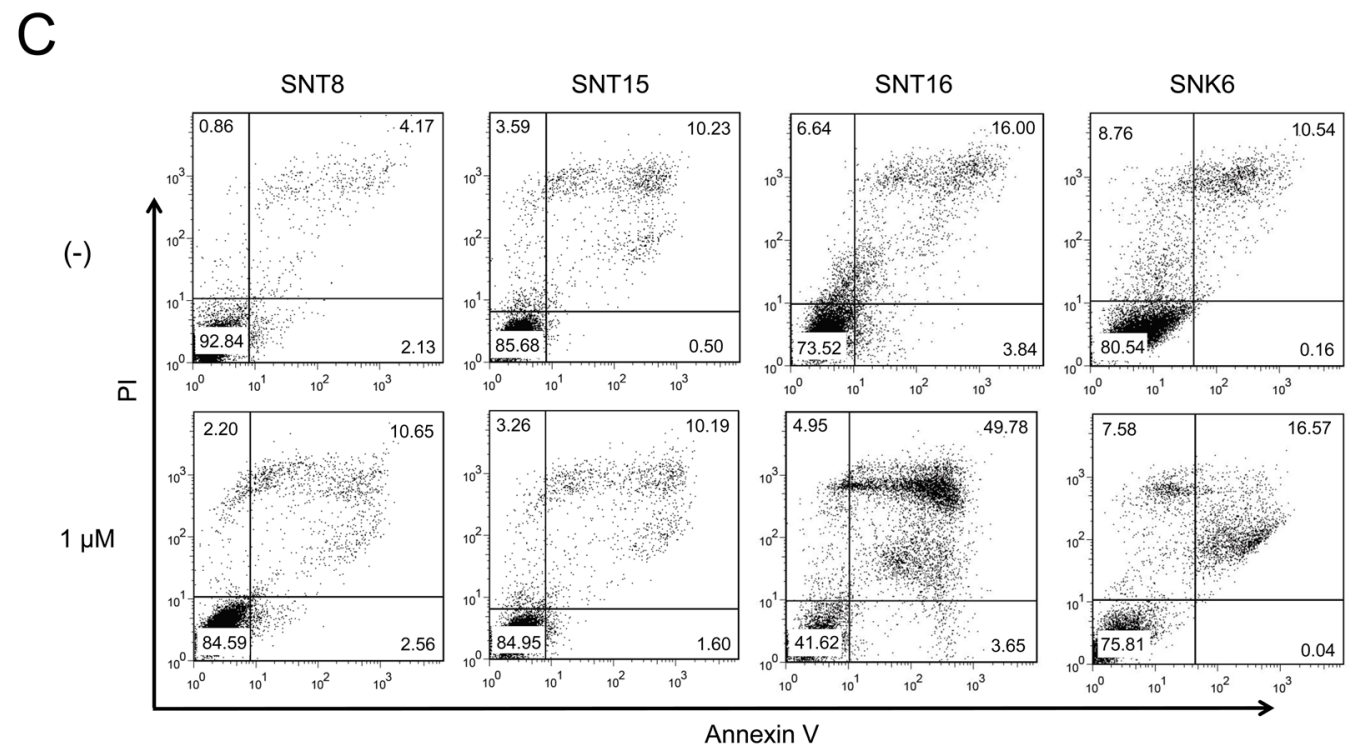

Figure 4: Ruxolitinib suppresses viable cell number of EBV-infected T or NK cells. (A) EBV-infected T- or NK-cell lines were treated with ruxolitinib, as indicated, for $48 \mathrm{~h}$, and the number of viable cells was estimated by an XTT assay and expressed in arbitrary units. The data are shown as mean \pm standard deviations (SD) of three independent experiments. (B) the PBMCs from 3 patients with CAEBV and 1 healthy donor were treated with ruxolitinib, as indicated, in the presence of IL- 2 for $72 \mathrm{~h}$, and the viable cell number was estimated by an XTT assay and expressed in arbitrary units. The data are presented as mean \pm SD of three independent experiments. (C) EBV-infected T- or NK-cell lines were treated with ruxolitinib for $48 \mathrm{~h}$, as indicated, and then analyzed. Cells were stained with Annexin $\mathrm{V}$ and PI and subsequently analyzed by flow cytometry. 
in CAEBV, and the effects of ruxolitinib on EGFR warrant further investigation. Overall, NF- $\kappa \mathrm{B}$ might induce STAT3 activation through IL-6 or EGFR in EBV-infected T or NK cells. Furthermore, other molecular pathways can contribute to the activation of STAT3 in EBV-infected T or NK cells. Erk is reportedly activated downstream of LMP1 and induces the serine phosphorylation of STAT3 [32]. Our recent study determined that Erk was constitutively activated in EBV-infected T or NK cells (our unpublished data). Additional studies in this regard are ongoing in our laboratory.

In this study, we determined that ruxolitinib suppresses the phosphorylation of STAT3, decreasing the survival and cytokine production in EBV-positive cells of patients with CAEBV. However, ruxolitinib-induced apoptosis was not clear in SNT8, SNT15 and SNK6 cells (Figure 4C). Additional mechanisms, such as necrosis or other types of programmed cell death, might be induced by the treatment. It is indispensable to confirm the effects using PBMCs of patients with CAEBV.

The two features of CAEBV are a neoplastic disease and an inflammatory disease. Since the concentration of inflammatory cytokines in the serum of patients with CAEBV is closely related to the disease status [19], these results suggest that ruxolitinib is effective for CAEBV treatment by suppressing both neoplastic cells and inflammation. Interestingly, two studies recently reported that JAK $1 / 2$ inhibition was effective in treating a mouse model of HLH [33, 34]. HLH, a severe form of inflammation, occurs in $24 \%$ of patients with CAEBV and can be lethal [9]. Inhibition of the JAK/STAT pathway might inhibit the development of HLH and could be an attractive candidate for CAEBV treatment. Nonetheless, further extensive studies using clinical samples are needed to confirm the results and apply these findings clinically.
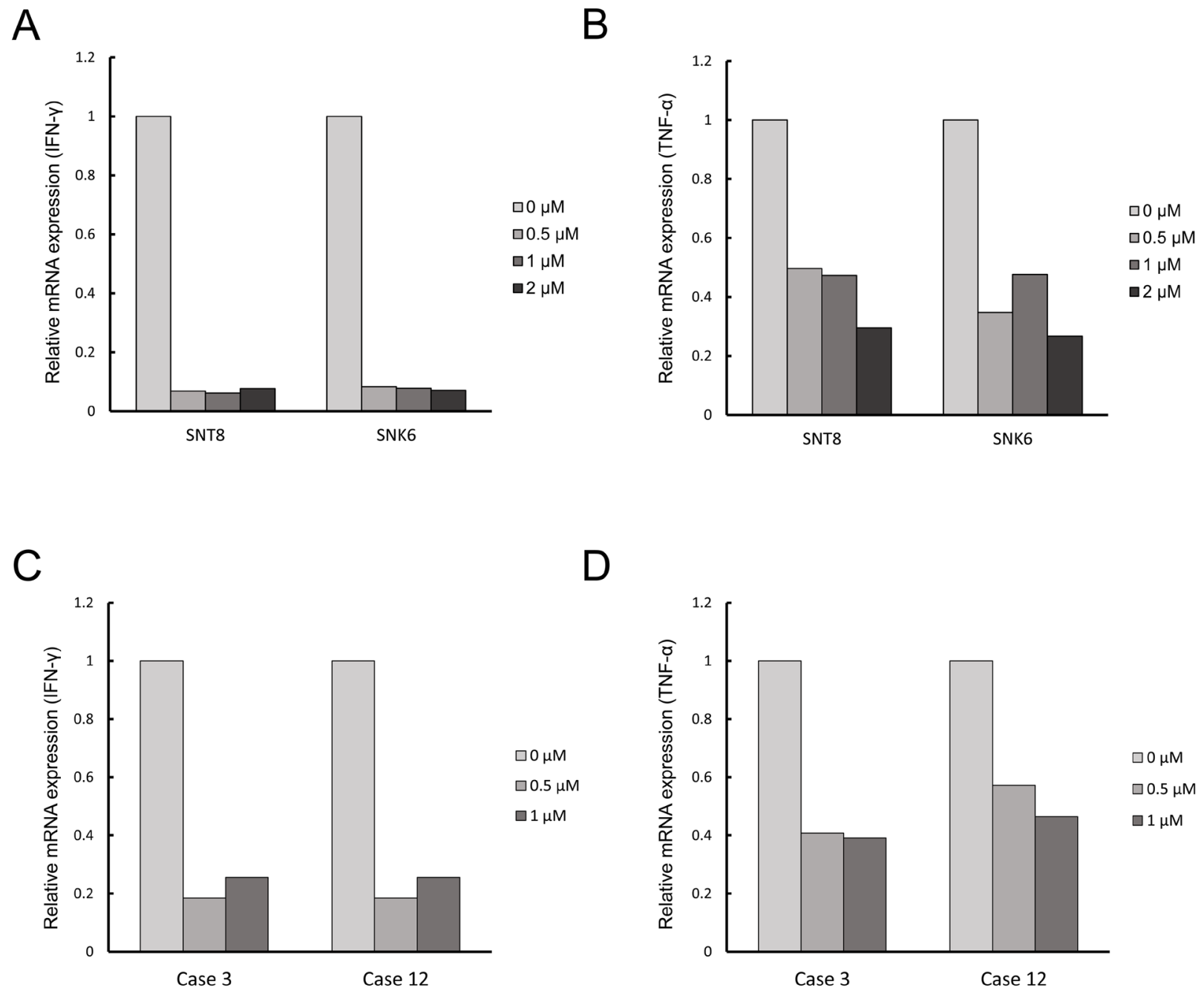

Figure 5: Ruxolitinib suppresses the mRNA expression of inflammatory cytokines in EBV-infected T- or NK-cells. (A and B) EBV-infected T- or NK-cell lines were treated with ruxolitinib, as indicated, for $24 \mathrm{~h}$. The RNA was extracted and subjected to quantitative PCR assays. (A) IFN- $\gamma$; (B) TNF-a; (C and D), the PBMCs from patients with CAEBV were treated with ruxolitinib, as indicated, for $24 \mathrm{~h}$. The RNA was extracted and used for quantitative PCR assays. (C) IFN- $\gamma$; (D) TNF-a. 


\section{MATERIALS AND METHODS}

\section{Cells and reagents}

EBV-T/NK-cell lines SNT8, SNT15, SNT16, SNK1, SNK6, and SNK10 were cultured in RPMI-1640 containing $10 \%$ fetal calf serum (10\% FCS-RPMI) and $175 \mathrm{U} / \mathrm{mL}$ human IL-2 [35]. The EBV-negative T- and NK-cell lines Jurkat, MOLT4, and HPB-ALL were cultured in 10\% FCS-RPMI, whereas the EBV-negative NK-cell line KHYG1 was cultured in 10\% FCS-RPMI containing $175 \mathrm{U} / \mathrm{mL}$ human IL-2. IL-2 was purchased from R\&D Systems (Abington, UK). Ruxolitinib and tofacitinib were purchased from LC Laboratories (Boston, MA). Jak inhibitor 1 was purchased from Merck Millipore (MA). DMSO was purchased from Wako Pure Chemical Industries (Osaka, Japan).

\section{Diagnosis of CAEBV}

CAEBV was diagnosed on the basis of following criteria: (1) the presence of characteristic clinical findings such as persistent systemic inflammation, fever, liver dysfunction, lymphadenitis, vasculitis, uveitis, severe mosquito bite allergy (sMBA), and hydroa vacciniforme-like eruption (HV); (2) a high EBV load detected in the PBMCs by quantitative PCR ( $>10^{2.5}$ copies/ $\mu \mathrm{g}$ of EBV DNA); and (3) EBV infection in T or NK cells $[5,36]$. The clonality of the infected cells was examined by Southern blotting.

\section{Detection of EBV-infected cells in patients with CAEBV}

Infected cells were detected and isolated as described previously [37]. Briefly, the PBMCs obtained from patients were isolated by density gradient centrifugation using Separate-L (Muto Pure Chemical, Tokyo, Japan) and were sorted into CD19-, CD4-, CD8, or CD56-positive fractions using antibody-conjugated magnetic beads (Miltenyi Biotec, Bergisch Gladbach, Germany; 130-050-301, 130-045-101, 130-045-201, 130090-875). After that, the EBV DNA levels in each fraction were evaluated by real-time PCR using the TaqMan System (Applied Biosystems, Foster City, CA) [38].

\section{Detection of the clonality}

The clonal proliferation of EBV-infected cells was detected by Southern blotting for EBV-terminal repeat. [39].

\section{Isolation of the EBV-infected cell fraction from patients with CAEBV}

For assays, we isolated the fraction containing EBVinfected cells from the PBMCs using antibody-conjugated magnetic beads against a surface marker on infected cells (IMag Anti-Human CD4, 8, or 56 Particles-DM; BD Biosciences). Table 1 describes the marker used to isolate infected cells from each patient.

\section{Apoptosis detection assay}

Apoptosis was detected using a TACS ${ }^{\circledR}$ Annexin V-FITC apoptosis detection kit (Trevigen, Gaithersburg, $\mathrm{MD})$, according to the manufacturer's instructions.

\section{XTT assay}

The XTT assay was performed according to the sodium 3V-(1-[phenylaminocarbonyl]-3,4-tetrazolium)bis(4-methoxy-6-nitro)-benzene sulfonic acid hydrate (XTT) colorimetric method using the Cell Proliferation Kit II (Roche Molecular Biochemicals, Indianapolis, IN), according to the manufacturer's instructions.

\section{Antibodies}

For western blotting, we used the following antibodies: phospho-STAT3 (Tyr705, No.9145); phosphoSTAT3 (Ser727, No.9134; Cell Signaling Technology, Danvers, MA); and Hsp90a/ $/$ (F-8, No.SC13119; Santa Cruz Biotechnology, CA). For immunofluorescence staining, we used an antibody against STAT3 (H-190, No.SC7179; Santa Cruz Biotechnology).

\section{Cell lysis for western blotting}

The assay was performed as described previously [40]. For total cell lysis, cells were lysed in SIP buffer (50 mM Tris- $\mathrm{HCl}$ [pH 7.5], $5 \mathrm{mM}$ EDTA, $100 \mathrm{mM} \mathrm{NaCl}, 50$ $\mathrm{mM} \mathrm{NaF}, 1 \mathrm{mM} \mathrm{Na}_{3} \mathrm{VO}_{4}, 40 \mathrm{mM} \beta$-glycerophosphate, and $1 \%$ Triton X-100) after washing with phosphate buffered saline (PBS). The resulting lysate was centrifuged at $15,000 \mathrm{rpm}$ for $10 \mathrm{~min}$, and the supernatant was collected and subjected to western blotting.

Furthermore, proteins were separated into cytoplasmic and nuclear fractions, as described later. After washing with PBS, cells were lysed in hypotonic buffer $(50 \mathrm{mM}$ Tris$\mathrm{HCl}$ [pH 7.5], $5 \mathrm{mM}$ EDTA, $10 \mathrm{mM} \mathrm{NaCl}, 1 \mathrm{mM} \mathrm{NaF}, 1$ $\mathrm{mM} \mathrm{Na}_{3} \mathrm{VO}_{4}$, and $0.05 \% \mathrm{NP}-40$ ). Lysates were centrifuged at $700 \times \mathrm{g}$ for $2 \mathrm{~min}$, and supernatants were collected as cytoplasmic protein fractions. Pellets were washed three times with hypotonic buffer and lysed in SIP buffer (50 $\mathrm{mM}$ Tris-HCl [pH 7.5], $5 \mathrm{mM}$ EDTA, $100 \mathrm{mM} \mathrm{NaCl}, 50$ $\mathrm{mM} \mathrm{NaF}, 1 \mathrm{mM} \mathrm{Na}_{3} \mathrm{VO}_{4}, 40 \mathrm{mM} \beta$-glycerophosphate, and $1 \%$ Triton X-100). Lysates were centrifuged at $15,000 \mathrm{rpm}$ for $10 \mathrm{~min}$, and supernatants were used as nuclear protein fractions. Proteins were quantified using the DC protein assay kit (Bio-Rad, Hercules, CA) and equivalent protein quantities were subjected to western blotting.

The relative intensities of bands were determined by densitometry using ImageJ software (https://imagej.nih.gov/ij/).

\section{Immunofluorescence staining}

Cells were fixed on slides by immersion in $4 \%$ paraformaldehyde for $10 \mathrm{~min}$, followed by three washes in PBS and were incubated with mouse monoclonal 
anti-LMP1 and rabbit polyclonal anti-phospho-STAT3 (Tyr705) antibodies at room temperature. Then, the slides were treated at room temperature with a Cy5-conjugated AffiniPure donkey anti-mouse antibody (No.715-175-151, Jackson ImmunoResearch Laboratories, Inc., West Grove, PA) to label the anti-LMP1 antibody and a PE-conjugated goat anti-rabbit antibody (No. 4030-09; Southern Biotech, Birmingham, AL) to label the anti-phospho-STAT3 antibody. The nuclei were counterstained with ProLong Gold and DAPI (Invitrogen, Carlsbad, CA).

\section{Microarray analysis}

The total RNA was extracted from the EBV-infected cell fraction of the PBMCs obtained from patients with CAEBV using TRIzol Reagent (Thermo Fisher Scientific K.K, Waltham, MA) and purified using the SV Total RNA Isolation System (Promega, Madison, WI), according to the manufacturer's instructions. We quantified RNA samples by an ND-1000 spectrophotometer (NanoDrop Technologies, Wilmington, DE) and confirmed the quality with the Experion System (Bio-Rad Laboratories). The cRNA was amplified, labeled using the Low Input Quick Amp Labeling Kit, and hybridized to a SurePrint G3 Human Gene Expression Microarray $8 \times 60 \mathrm{~K}$ v2 (Agilent Technology, Santa Clara, CA), according to the manufacturer's instructions. All hybridized microarray slides were scanned by an Agilent scanner. Furthermore, relative hybridization intensities and background hybridization values were calculated using Agilent Feature Extraction Software (9.5.1.1; Agilent Technology).

We calculated raw signal intensities and flags for each probe from hybridization intensities (gProcessedSignal) and spot information (gIsSaturated), according to the manufacturer's instructions (Agilent). In addition, raw signal intensities were normalized by a quantile algorithm using the "preprocessCore" library package in the Bioconductor software $[41,42]$.

\section{Flow cytometry}

The PBMCs were isolated and analyzed by a FACS Calibur flow cytometer (Becton Dickinson and Company, Franklin Lakes, NJ) with FITC-conjugated mouse antihuman CD4 and PE-conjugated mouse anti-human CD56 antibodies (No.561842, No.555516; Becton Dickinson and Company).

\section{qRT-PCR}

The RNA was extracted with ISOGEN II (Nippon Gene, Tokyo, Japan) from the cell lines and PBMCs, and cDNA was generated using Transcriptor Universal cDNA Master (Roche, Basel, Switzerland). The DNase treatment was performed using shrimp DNase recombinant (Affymetrix, Santa Clara, CA). In addition, we performed qRT-PCR analyses on a Light Cycler 480
(Roche) using TaqMan ${ }^{\circledR}$ Gene Expression Assays (Applied Biosystems). The primers for interferon- $\gamma$ and TNF-a were Hs00989291_m1 and Hs01113624_g1, respectively.

\section{DNA sequencing}

In this study, genomic DNA was extracted using the DNeasy Blood \& Tissue Kit (QIAGEN, Hilden, Germany). PCR analyses of genomic DNA were performed in a $50 \mu \mathrm{L}$ reaction volume containing $5 \times$ prime STAR GXL Buffer, a dNTP mixture, a forward primer $(10 \mu \mathrm{M})$, a reverse primer $(10 \mu \mathrm{M})$, and Prime STAR GXL DNA polymerase (TAKARA BIO, Shiga, Japan); the primers used in this study have been previously described [20]. The PCR product was run on an agarose gel, excised with a scalpel, and purified using the MinElute Gel Extraction Kit (QIAGEN, Hilden, Germany). Furthermore, sequencing was performed using Ion PGM (Life Technologies, CA).

\section{Ethics statement}

The study was conducted in accordance with the principles of the Declaration of Helsinki and was approved by the ethical committee of the Tokyo Medical and Dental University (TMDU, Tokyo, Japan). We obtained written informed consent from all patients before enrollment in this study.

\section{Author contributions}

E.O., H.S., H.T., K-I.I., and A.A. designed the research, performed experiments, and analyzed data; S.A, M.Y., and N.S. performed experiments and analyzed data; S.F., T.K., and O.M designed the research and analyzed data; and E.O. and A.A. wrote the initial draft of the manuscript; and all authors contributed to the modification of the draft and approved the final submission.

\section{ACKNOWLEDGMENTS}

We are grateful to Ms. Kaori Okada for excellent technical assistance.

\section{CONFLICTS OF INTEREST}

The authors declare no competing financial interest.

\section{FUNDING}

This work was supported by grants from the Practical Research Project for Rare/Intractable Diseases (15ek0109098 and 18ek0109334h0001), from Japan Agency for Medical Research and Development, AMED, Japan Medical Association (CCT-A-2901), and the Ministry of Education, Culture, Sports, Science, and Technology of Japan (15K09468). 


\section{REFERENCES}

1. Virelizier JL, Lenoir G, Griscelli C. Persistent Epstein-Barr virus infection in a child with hypergammaglobulinaemia and immunoblastic proliferation associated with a selective defect in immune interferon secretion. Lancet. 1978; $2: 231-4$

2. Jones JF, Shurin S, Abramowsky C, Tubbs RR, Sciotto CG, Wahl R, Sands J, Gottman D, Katz BZ, Sklar J. T-cell lymphomas containing Epstein-Barr viral DNA in patients with chronic Epstein-Barr virus infections. N Engl J Med. 1988; 318:733-41. https://doi.org/10.1056/NEJM198803243181203.

3. Kimura H, Hoshino Y, Kanegane H, Tsuge I, Okamura T, Kawa K, Morishima T. Clinical and virologic characteristics of chronic active Epstein-Barr virus infection. Blood. 2001; 98:280-6.

4. Kawa K, Okamura T, Yagi K, Takeuchi M, Nakayama M, Inoue M. Mosquito allergy and Epstein-Barr virusassociated T/natural killer-cell lymphoproliferative disease. Blood. 2001; 98:3173-4.

5. Kimura H, Ito Y, Kawabe S, Gotoh K, Takahashi Y, Kojima S, Naoe T, Esaki S, Kikuta A, Sawada A, Kawa K, Ohshima K, Nakamura S. EBV-associated T/NK-cell lymphoproliferative diseases in nonimmunocompromised hosts: prospective analysis of 108 cases. Blood. 2012; 119:673-86. https://doi.org/10.1182/blood-2011-10-381921.

6. Quintanilla-Martinez L, Ko YH, Kimura H, Jaffe ES. EBVpositive T-cell and NK-cell lymphoproliferative diseases of childhood. In: Swerdlow S, Campo E, Harris NL, eds; WHO Classification of Tumours of Haematopoietic and Lymphoid Tissue. Lyon IARC Press. 2017; 355-363.

7. Kimura H. Pathogenesis of chronic active Epstein-Barr virus infection: is this an infectious disease, lymphoproliferative disorder, or immunodeficiency? Rev Med Virol. 2006; 16:251-61. https://doi.org/10.1002/rmv.505.

8. Fujiwara S, Kimura H, Imadome K, Arai A, Kodama E, Morio T, Shimizu N, Wakiguchi H. Current research on chronic active Epstein-Barr virus infection in Japan. Pediatr Int. 2014; 56:159-66. https://doi.org/10.1111/ped.12314.

9. Arai A, Sakashita C, Hirose C, Imadome KI, Yamamoto M, Jinta M, Fujiwara S, Tomita M, Shimizu N, Morio T, Miura O. Hematopoietic stem cell transplantation for adults with EBV-positive T- or NK-cell lymphoproliferative disorders: efficacy and predictive markers. Bone Marrow Transplant. 2016; 51:879-82. https://doi.org/10.1038/bmt.2016.3.

10. Yoshimori $M$, Takada $H$, Imadome $K$, Kurata $M$, Yamamoto K, Koyama T, Shimizu N, Fujiwara S, Miura $\mathrm{O}$, Arai A. P-glycoprotein is expressed and causes resistance to chemotherapy in EBV-positive T-cell lymphoproliferative diseases. Cancer Med. 2015; 4:1494 504. https://doi.org/10.1002/cam4.494.

11. Kawa K, Sawada A, Sato M, Okamura T, Sakata N, Kondo O, Kimoto T, Yamada K, Tokimasa S, Yasui M, Inoue M. Excellent outcome of allogeneic hematopoietic SCT with reduced-intensity conditioning for the treatment of chronic active EBV infection. Bone Marrow Transplant. 2011; 46:77-83. https://doi.org/10.1038/bmt.2010.122.

12. Scott LM, Gandhi MK. Deregulated JAK/STAT signalling in lymphomagenesis, and its implications for the development of new targeted therapies. Blood Rev. 2015; 29:405-15. https://doi.org/10.1016/j.blre.2015.06.002.

13. Levy DE, Lee CK. What does Stat3 do? J Clin Invest. 2002; 109:1143-8. https://doi.org/10.1172/JCI15650.

14. Nepomuceno RR, Snow AL, Robert Beatty P, Krams SM, Martinez OM. Constitutive activation of Jak/STAT proteins in Epstein-Barr virus-infected B-cell lines from patients with posttransplant lymphoproliferative disorder. Transplantation. 2002; 74:396-402.

15. Kato H, Karube K, Yamamoto K, Takizawa J, Tsuzuki S, Yatabe Y, Kanda T, Katayama M, Ozawa Y, Ishitsuka K, Okamoto M, Kinoshita T, Ohshima K, et al. Gene expression profiling of Epstein-Barr virus-positive diffuse large B-cell lymphoma of the elderly reveals alterations of characteristic oncogenetic pathways. Cancer Sci. 2014; 105:537-44. https://doi.org/10.1111/cas.12389.

16. Lui VW, Wong EY, Ho Y, Hong B, Wong SC, Tao Q, Choi GC, Au TC, Ho K, Yau DM, Ma BB, Hui EP, Chan AS, et al. STAT3 activation contributes directly to EpsteinBarr virus-mediated invasiveness of nasopharyngeal cancer cells in vitro. Int J Cancer. 2009; 125:188493. https://doi.org/10.1002/ijc.24567.

17. Coppo P, Gouilleux-Gruart V, Huang Y, Bouhlal H, Bouamar H, Bouchet S, Perrot C, Vieillard V, Dartigues P, Gaulard P, Agbalika F, Douay L, Lassoued K, et al. STAT3 transcription factor is constitutively activated and is oncogenic in nasal-type NK/T-cell lymphoma. Leukemia. 2009; 23:1667-78. https://doi.org/10.1038/leu.2009.91.

18. Küçük C, Jiang B, Hu X, Zhang W, Chan JK, Xiao W, Lack N, Alkan C, Williams JC, Avery KN, Kavak P, Scuto A, Sen E, et al. Activating mutations of STAT5B and STAT3 in lymphomas derived from $\gamma \delta$-T or NK cells. Nat Commun. 2015; 6:6025. https://doi.org/10.1038/ncomms7025.

19. Arai A, Nogami A, Imadome KI, Kurata M, Murakami N, Fujiwara S, Miura O. Sequential monitoring of serum IL-6, TNF- $\alpha$, and IFN- $\gamma$ levels in a CAEBV patient treated by plasma exchange and immunochemotherapy. Int J Hematol. 2012; 96:66973. https://doi.org/10.1007/s12185-012-1170-2.

20. Koskela HL, Eldfors S, Ellonen P, van Adrichem AJ, Kuusanmäki H, Andersson EI, Lagström S, Clemente MJ, Olson T, Jalkanen SE, Majumder MM, Almusa H, Edgren H, et al. Somatic STAT3 mutations in large granular lymphocytic leukemia. N Engl J Med. 2012; 366:1905-13. https://doi.org/10.1056/NEJMoa1114885.

21. Yang S, Luo C, Gu Q, Xu Q, Wang G, Sun H, Qian Z, Tan Y, Qin Y, Shen Y, Xu X, Chen SH, Chan CC, et al. Activating JAK1 mutation may predict the sensitivity of JAK-STAT 
inhibition in hepatocellular carcinoma. Oncotarget. 2016; 7:5461-9. https://doi.org/10.18632/oncotarget.6684.

22. Koo GC, Tan SY, Tang T, Poon SL, Allen GE, Tan L, Chong SC, Ong WS, Tay K, Tao M, Quek R, Loong S, Yeoh KW, et al. Janus kinase 3-activating mutations identified in natural killer/T-cell lymphoma. Cancer Discov. 2012; 2:591-7. https://doi.org/10.1158/2159-8290.CD-12-0028.

23. Bouchekioua A, Scourzic L, de Wever O, Zhang Y, Cervera P, Aline-Fardin A, Mercher T, Gaulard P, Nyga R, Jeziorowska D, Douay L, Vainchenker W, Louache F, et al. JAK3 deregulation by activating mutations confers invasive growth advantage in extranodal nasal-type natural killer cell lymphoma. Leukemia. 2014; 28:338-48. https://doi.org/10.1038/leu.2013.157.

24. Kimura H, Karube K, Ito Y, Hirano K, Suzuki M, Iwata $\mathrm{S}$, Seto M. Rare occurrence of JAK3 mutations in natural killer cell neoplasms in Japan. Leuk Lymphoma. 2014; 55:962-3. https://doi.org/10.3109/10428194.2013.819577.

25. Heinrich T, Rengstl B, Muik A, Petkova M, Schmid F, Wistinghausen R, Warner K, Crispatzu G, Hansmann ML, Herling M, von Laer D, Newrzela S. Mature T-cell lymphomagenesis induced by retroviral insertional activation of Janus kinase 1. Mol Ther. 2013; 21:1160-8. https://doi.org/10.1038/mt.2013.67.

26. Wang L, Ren J, Li G, Moorman JP, Yao ZQ, Ning S. LMP1 signaling pathway activates IRF4 in latent EBV infection and a positive circuit between PI3K and $\mathrm{Src}$ is required. Oncogene. 2017; 36:2265-74. https://doi.org/10.1038/onc.2016.380.

27. Kung CP, Raab-Traub N. Epstein-Barr virus latent membrane protein 1 induces expression of the epidermal growth factor receptor through effects on Bcl-3 and STAT3. J Virol. 2008; 82:5486-93. https://doi.org/10.1128/JVI.00125-08.

28. Busch LK, Bishop GA. Multiple carboxyl-terminal regions of the EBV oncoprotein, latent membrane protein 1, cooperatively regulate signaling to $\mathrm{B}$ lymphocytes via TNF receptor-associated factor (TRAF)-dependent and TRAFindependent mechanisms. J Immunol. 2001; 167:5805-13.

29. Takada H, Imadome KI, Shibayama H, Yoshimori M, Wang L, Saitoh Y, Uota S, Yamaoka S, Koyama T, Shimizu N, Yamamoto K, Fujiwara S, Miura O, et al. EBV induces persistent NF- $\kappa \mathrm{B}$ activation and contributes to survival of EBV-positive neoplastic T- or NK-cells. PLoS One. 2017; 12:e0174136. https://doi.org/10.1371/journal.pone.0174136.

30. Chen H, Hutt-Fletcher L, Cao L, Hayward SD. A positive autoregulatory loop of LMP1 expression and STAT activation in epithelial cells latently infected with EpsteinBarr virus. J Virol. 2003; 77:4139-48.

31. Nosbaum A, Prevel N, Truong HA, Mehta P, Ettinger M, Scharschmidt TC, Ali NH, Pauli ML, Abbas AK, Rosenblum MD. Cutting edge: regulatory T cells facilitate cutaneous wound healing. J Immunol. 2016; 196:2010-4. https://doi.org/10.4049/jimmunol.1502139.
32. Kung CP, Meckes DG, Raab-Traub N. Epstein-Barr virus LMP1 activates EGFR, STAT3, and ERK through effects on PKCdelta. J Virol. 2011; 85:4399-408. https://doi.org/10.1128/JVI.01703-10.

33. Das R, Guan P, Sprague L, Verbist K, Tedrick P, An QA, Cheng C, Kurachi M, Levine R, Wherry EJ, Canna SW, Behrens EM, Nichols KE. Janus kinase inhibition lessens inflammation and ameliorates disease in murine models of hemophagocytic lymphohistiocytosis. Blood. 2016; 127:1666-75. https://doi.org/10.1182/blood-2015-12-684399.

34. Maschalidi S, Sepulveda FE, Garrigue A, Fischer A, de Saint Basile G. Therapeutic effect of JAK1/2 blockade on the manifestations of hemophagocytic lymphohistiocytosis in mice. Blood. 2016; 128:60-71. https://doi.org/10.1182/blood-2016-02-700013.

35. Zhang Y, Nagata H, Ikeuchi T, Mukai H, Oyoshi MK, Demachi A, Morio T, Wakiguchi H, Kimura N, Shimizu $\mathrm{N}$, Yamamoto K. Common cytological and cytogenetic features of Epstein-Barr virus (EBV)-positive natural killer (NK) cells and cell lines derived from patients with nasal T/NK-cell lymphomas, chronic active EBV infection and hydroa vacciniforme-like eruptions. Br J Haematol. 2003; 121:805-14.

36. Okano M, Kawa K, Kimura H, Yachie A, Wakiguchi H, Maeda A, Imai S, Ohga S, Kanegane H, Tsuchiya S, Morio T, Mori M, Yokota S, et al. Proposed guidelines for diagnosing chronic active Epstein-Barr virus infection. Am J Hematol. 2005; 80:64-9. https://doi.org/10.1002/ajh.20398.

37. Yoshimori M, Imadome KI, Komatsu H, Wang L, Saitoh Y, Yamaoka S, Fukuda T, Kurata M, Koyama T, Shimizu N, Fujiwara S, Miura O, Arai A. CD137 expression is induced by Epstein-Barr virus infection through LMP1 in T or NK cells and mediates survival promoting signals. PLoS One. 2014; 9:e112564. https://doi.org/10.1371/journal.pone.0112564.

38. Kimura H, Morita M, Yabuta Y, Kuzushima K, Kato K, Kojima S, Matsuyama T, Morishima T. Quantitative analysis of Epstein-Barr virus load by using a real-time PCR assay. J Clin Microbiol. 1999; 37:132-6.

39. Raab-Traub N, Flynn K. The structure of the termini of the Epstein-Barr virus as a marker of clonal cellular proliferation. Cell. 1986; 47:883-9.

40. Arai A, Kanda E, Miura O. Rac is activated by erythropoietin or interleukin-3 and is involved in activation of the Erk signaling pathway. Oncogene. 2002; 21:2641-51. https://doi.org/10.1038/sj.onc.1205346.

41. Bolstad BM, Irizarry RA, Astrand M, Speed TP. A comparison of normalization methods for high density oligonucleotide array data based on variance and bias. Bioinformatics. 2003; 19:185-93.

42. Gentleman RC, Carey VJ, Bates DM, Bolstad B, Dettling M, Dudoit S, Ellis B, Gautier L, Ge Y, Gentry J, Hornik K, Hothorn T, Huber W, et al. Bioconductor: open software development for computational biology and bioinformatics. Genome Biol. 2004; 5:R80. https://doi.org/10.1186/gb-2004-5-10-r80. 